\begin{tabular}{|c|c|c|c|}
\hline & $\begin{array}{l}\text { Escola Superior } \\
\text { de Gestáo } \\
\text { Teconologia } \\
\text { [ipsantaréém] }\end{array}$ & KU & $\begin{array}{l}\text { ISSN 2029-7564 (online) } \\
\text { SOCIALINĖS TECHNOLOGIJOS } \\
\text { SOCIAL TECHNOLOGIES } \\
2013,3(1), \text { p. } 104-114\end{array}$ \\
\hline
\end{tabular}

\title{
E. SVEIKATOS ADMINISTRAVIMO SISTEMOS KOMUNIKACIJOS RODIKLIAI IR JŲ REIKŠMINGUMO VERTINIMAS
}

\author{
Ramutè Naujikienè \\ Mykolo Romerio universitetas, Lietuva, riman@mruni.eu
}

doi:10.13165/ST-13-3-1-07

\section{Santrauka}

Tikslas - kaip efektyviau panaudoti informaciniu technologiju bei skaitmeniniu komunikaciniu tinklu galimybes gyventoju sveikatos administravimo problemoms spręsti. Pateikti e. sveikatos administravimo sistemos komunikacijos rodiklius ir ju vertinima, kurie užtikrintu e. paslaugu teikimo internetu kokybę ir tenkintu gyventojų lükesčius.

Metodologija - mokslines literatūros analizé - atliekama siekiant pateikti e. paslaugu administracinès naštos poveiki vartotojui. Pateikti vartotoju pageidaujami sveikatos komunikacijos rodikliai, atliktas ekspertinis tyrimas, apskaičiuotos sveikatos komunikacijos rodikliu svorio reikšmes bei apibendrinti tyrimo rezultatai.

Rezultatai - svarbiu veiksniu, skatinančiu naudotis e. sveikatos administravimo paslaugomis ir didinančiu paslaugos veiksminguma, tampa e. paslaugos poveikis gyventojams, kuri siūloma vertinti pagal: paslaugos pateikimo kokybe - suprantama ir paprasta e. paslaugos atlikimo eiga; vartotoju technines ir skaitmeninio raštingumo galimybes - kompiuterine, programine iranga ir interneto prieiga.

Tyrimo ribotumas - administravimo sistemoje igyvendinant inovatyvius sprendimus komunikacijos rodikliu reikšmingumas taip pat keisis.

Praktine reikšme - sveikatos priežiūros organizacijos, naudodamos IKT priemones, didins savo veiklos efektyvuma ir veiksminguma ir taip gerins administravimo paslaugas bei mažins administracinę naštą gyventojams. 
Originalumas / vertingumas - straipsnyje pateikiami tyrimo rezultatai, kurie paaiškina, kaip reiketu efektyviau panaudoti informaciniu technologiju bei skaitmeniniu komunikaciniu tinklu galimybes gyventoju sveikatos administravimo problemoms spręsti.

Raktažodžiai: e. paslaugos, e. sveikata, komunikacija, administracine našta, sąveikumas, informacines komunikacines technologijos.

Tyrimo tipas: tyrimo pristatymas, požiūrio pristatymas, literatūros apžvalga.

\section{Ivadas}

E. sveikata yra nauja sveikatos apsaugos, medicininès informatikos ir administracinès veiklos sandūros sritis, skirta sveikatos paslaugoms ir jai reikalingai informacijai pateikti bei tobulinti panaudojant internetą ir panašias technologijas. Platesne prasme šis terminas reiškia ne tik technologinę plètrą, bet taip pat sąmoningumo lygị, mąstymo būdą, požiūrị ir atsidavimą globaliai, tinklinei veiklai ir mąstymui, leidžiančiam esmingai pagerinti sveikatos apsaugos paslaugas lokaliu, regioniniu ir pasauliniu lygiu panaudojant informacines ir komunikacijų technologijas. Pasaulio šalys, suprasdamos informacinių technologijų reikšmę, skiria didelį dèmesị jų panaudojimui sveikatos apsaugai. Visuma informacinių priemonių, naudojamų teikiant sveikatos paslaugas, apibendrintai vadinama elektroninès sveikatos sistema, arba tiesiog e. sveikata (EK komunikatas Nr. 356, 2004).

Lietuvoje e. sveikatos paslaugos gyventojams ir pacientams informacinejje erdvejje žymiai atsilieka nuo kitų e. paslaugų, nors sveikatos informacija yra labai svarbi. Nepakankamai integruotos asmens ir visuomenès sveikatos sistemos. Ribota informacija apie sveikatos paslaugas ir jų teikẻjus, vietoj apsikeitimo informacija iš įstaigos ị ịstaigą siuntinejjami pacientai, nepasitikint tyrimų rezultatais arba neturint išsamios informacijos tyrimai dažnai dubliuojami. Reikètų efektyviau panaudoti didžiules informacinių technologijų, kompiuterizuotos medicininès įrangos bei skaitmeninių komunikacijos tinklų galimybes gyventojų sveikatos apsaugos problemoms spręsti. Informacinès technologijos čia atveria naujas galimybes gyventojų sveikatinimo, profilaktikos, gydymo tikslais visapusiškai panaudoti visą profesionalią informaciją (Įsakymas Nr. V-811, 2007).

Informacinių komunikacijos technologijų naudojimas turi didžiulę įtaką sveikatos priežiūros sistemai bei jos organizacijų vadybai. Informacinès komunikacinės technologijos sukuria naujas sveikatos priežiūros organizacijų ir gyventojų sąveikos galimybes. Didžiausias naudojimosi e. sveikatos informacine sistema privalumas tai, kad piliečiai gali atlikti daugelị reikalingų veiksmų, susijusių su e. sveikatos administravimo paslaugomis, internetu jiems patogiu laiku.

Dažniausiai informacinès sistemos sèkmę lemia:

- naudojamų išteklių savybès - personalo kvalifikacija, kompiuterizacijos lygmuo, pakankamas finansavimas ir pan.; 
- gebejjimai tenkinti funkcinius ar nefunkcinius veiklos reikalavimus - laiku ir gerai atlikti tam tikrus darbus;

- informacinių paslaugų pobūdis ir jų kokybė (Dzemydienė et al., 2010).

Kylant kompiuterizavimo ir interneto vartojimo lygiui, didejja e. sveikatos sistemu vartotojų (gyventojų, pacientų, gydytojų, administratorių) vaidmuo. Kuriamą e. sveikatos architektūrą stengiamasi padaryti atvirą ir evoliucionuojančią, lanksčiai atliepiančią vartotojų poreikius. Todėl vartotojams atsiveria galimybès daryti įtaką e. sveikatos sistemai (Issakymas Nr. V-811, 2007).

\section{Informacinių sistemų sąveikumo reikalavimai teikiant adminis- travimo paslaugas}

E. sveikatos strategija, kaip ir visa sistemos architektūra, yra sucentruota ị gyventojus ir pacientus. Personalizuotos paslaugos ir jų tęstinumas laike ir bet kurių paslaugas teikiančių institucijų atžvilgiu yra pagrindinè strategijos kryptis. Tai kelia didelius reikalavimus duomenų integravimui nacionaliniu mastu, valdymo sistemai ir bendradarbiavimo būdui (İsakymas Nr. V-811, 2007).

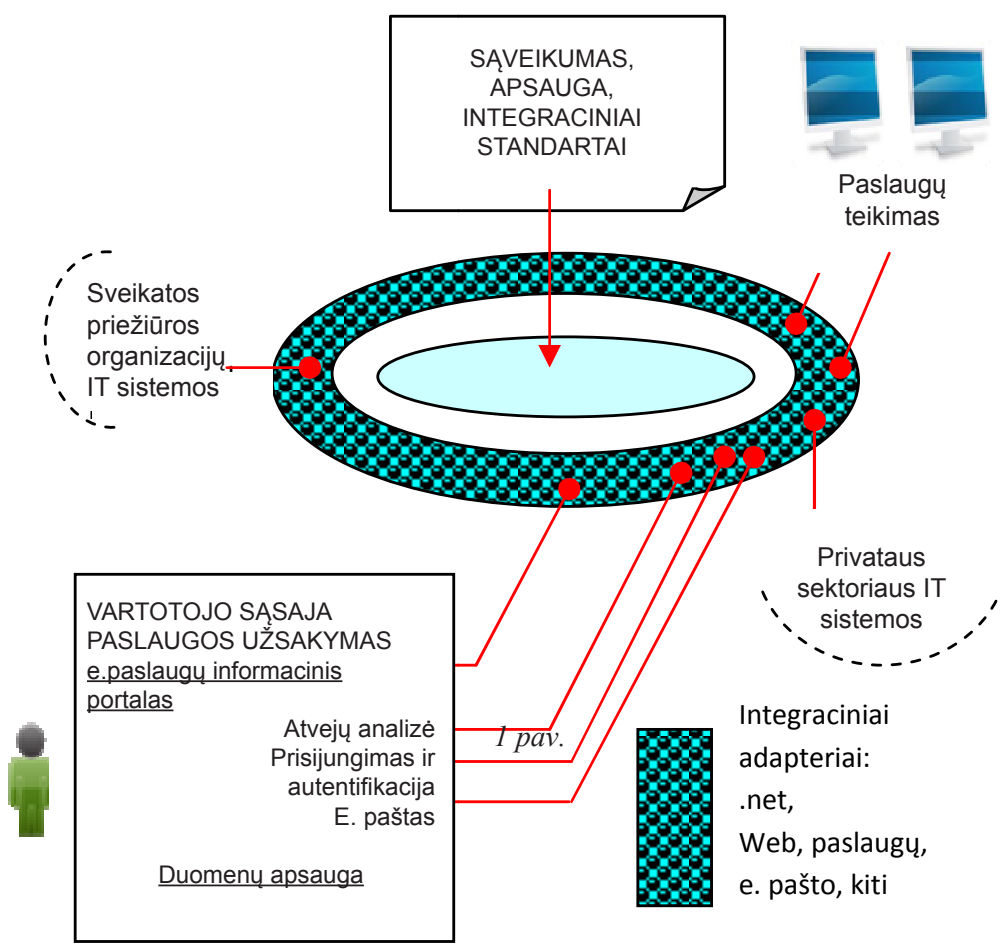

E. paslaugų sąveikumo užtikrinimo komponentai 
Norint sėkmingai išspręsti duomenų integravimo problemas svarbu užtikrinti jau veikiančių skirtingose sveikatos priežiūros organizacijose informacinių sistemų sąveikumą. Sąveikumo užtikrinimas grindžiamas integruota išskirstytų informacinių sistemų (IS) sąveikos infrastruktūra, kurios pagrindas - sukurti bendrą e. paslaugų platformą, kad e. paslaugų portalas leistų organizuoti saugią ir veiksmingą išskirstytų IS, registrų ir duomenų bazių (DB) sąveiką (Dzemydienè ir Naujikienė, 2007). E. paslaugų teikimo sąveikumo schema apibrèžiama kaip visuma standartų ir rekomendacijų, nusakančių būdus, kaip organizacijos turi susitarti ir organizuoti sistemų darbą, kad galètų tarpusavyje bendrauti (Pardo, 2011).

Sąveikumas (angl. interoperability) gali būti suprantamas kaip programinès ịrangos gebejjimas keistis skirtingų e. dokumentų formatų duomenimis, dalytis informacija ir žiniomis užtikrinant funkcinị jų suderinamumą (Gascó, 2010). IS sąveikumo reikalavimai ypač svarbūs teikiant paslaugas internetu.

IS sąveikumo reikalavimai apima gana daug nagrinėtinų kriterijų, kurie perteikiami atvirụjų standartų ir įvairių iniciatyvų priemonèmis, norint sukurti administravimo e. paslaugų tinklą, užtikrinti saugumo, asmens ar organizacijų tinkamą identifikavimą esant tokių sistemų sąveikai. E. paslaugų teikimo schema ir jos komponentai pateikiami 1 paveiksle. Naudojantis išoriniu tinklu, kai e. paslaugas gali teikti įvairios organizacijos, viena iš būtinų sąlygų yra IT sistemų sąveikumas.

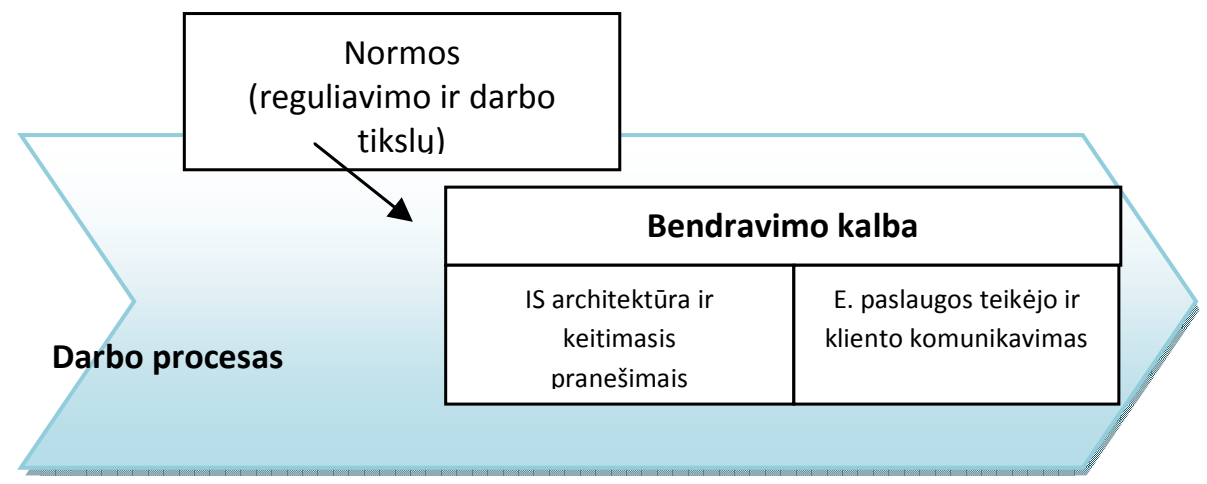

Šaltinis: schema sudaryta autorès pagal Goldkuhl and Röstlinger, 2010

2 pav. Kliento ir e. paslaugos teikèjo komunikacija - penki sudètiniai jos komponentai

Norint teikti kokybiškas i vartotoją orientuotas e. paslaugas nemažiau svarbi kliento ir paslaugos teikèjo komunikacija, kurią sudaro šie pagrindiniai komponentai: reguliavimo normos ir darbo tikslai, darbo procesas, bendravimo kalba, IS architektūra ir keitimasis pranešimais, paslaugos teikejjo ir kliento komunikavimas (Goldkhul and Röstlinger, 2010). Kliento ir viešosios paslaugos teikejjo komunikacijos schema vaizduojama 2 paveiksle. 


\section{Administracinès naštos piliečiams mažinimas ir vertinimas}

Kuriant informacinę sistemą pirmenybè turètų būti teikiama tokiai informacinei sistemai, kuri galètų pagerinti teikiamas paslaugas ir mažintų piliečių administracinę naštą. Daugelyje mokslinių tyrimų rodiklis „administracinès naštos sumažinimas“ yra ìvertintas kaip labiausiai piliečių pageidaujamas (Verdegem and Hauttekeete, 2007).

2011 m. vasario 23 d. Lietuvos Respublikos Vyriausybès nutarimas Nr. 213 „Dèl administracinès naštos piliečiams ir kitiems asmenims nustatymo ir ịvertinimo metodikos patvirtinimo" pateikia teisès akto sukeliamos administracinès naštos piliečiams ir kitiems asmenims apskaičiavimo struktūrą (žr. 3 pav.).

Dẻl veiksmo vykdymo patiriama administracinė našta apskaičiuojama padauginant laiką, per kurị pilietis atlieka ši vykdymo veiksmą, $(T)$ ir asmenines finansines išlaidas, kurias pilietis patiria atlikdamas ši vykdymo veiksmą, (C) iš kiekio kintamojo (Q), kuris parodo vykdymo veiksmo atlikimo dažnị (F) ir jị atliekančių piliečių skaičiu (L) (LRV nutarimas Nr. 213, 2011). Apskaičiuojama pagal (1) ir (2) formules:

$$
\begin{aligned}
& \mathrm{AN}_{\mathrm{vv}}=\mathrm{T}_{\mathrm{vv}} \times \mathrm{Q} \\
& \mathrm{AN}_{\mathrm{vv}}=\mathrm{C}_{\mathrm{vv}} \times \mathrm{Q}
\end{aligned}
$$

čia:

$\mathrm{AN}_{\mathrm{vv}}$ - dèl vykdymo veiksmo patiriama administracinè našta;

$\mathrm{T}_{\mathrm{vv}}$ - laikas, per kurị pilietis atlieka šị vykdymo veiksmą (valandomis);

$\mathrm{C}_{\mathrm{vv}}$ - asmeninės finansinès išlaidos, kurias pilietis patiria atlikdamas ši vykdymo veiksmą (litais);

Q - kiekio kintamasis, kuris apskaičiuojamas pagal (3) formulę:

$$
\mathrm{Q}=\mathrm{L} \times \mathrm{F}
$$

čia:

L - piliečių, privalančių atlikti atitinkamą vykdymo veiksmą, skaičius; apskaičiuojant ši kintamajị, daroma prielaida, kad visi piliečiai, kurie privalo vykdyti informacini ịpareigojimą, šio reikalavimo laikosi;

F - vykdymo veiksmo atlikimo dažnis per vienus kalendorinius metus.

Administracinę naštą sudarantis laikas ir administracinę naštą sudarančios asmeninès finansinès išlaidos yra reikšmingi rodikliai ir sveikatos administravimo sistemos komunikavimo procese gali piliečiams sumažinanti administracinę naštą, kai yra komunikuojama internetu. 


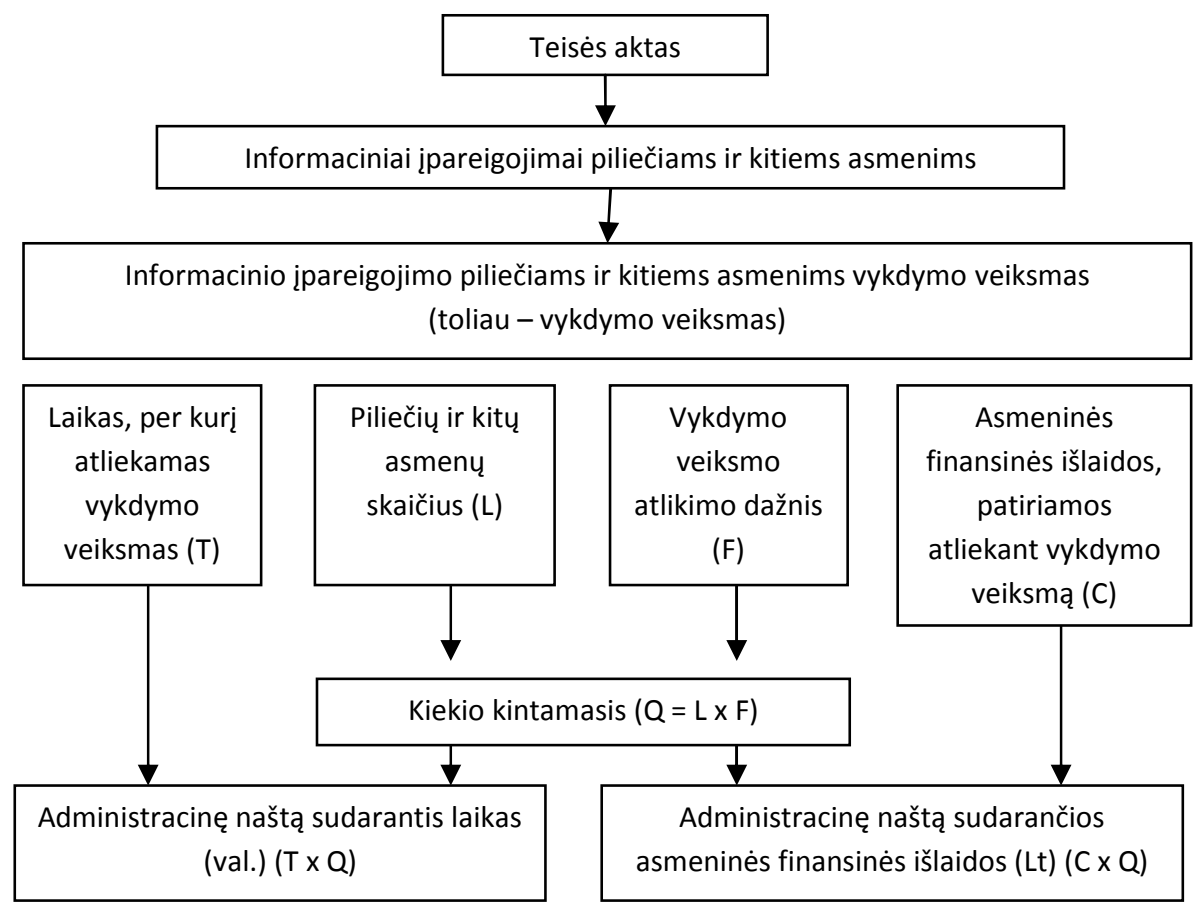

Šaltinis: LRV nutarimas Nr. 213, 2011

3 pav. Administracinès naštos piliečiams ir kitiems asmenims apskaičiavimo struktūra

\section{E. sveikatos administravimo sistemos komunikacijos rodikliai ir jų reikšmingumo vertinimas}

Sveikatos priežiūros sistemos ir jos organizacijų valdymo tobulinimas apima: sveikatos priežiūros vadybininkų profesionalų rengimą; valdymo decentralizaciją (sveikatos priežiūros valdymo (dalininkų ir steigèjų funkcijų) perdavimą savivaldybėms); konkurencijos ir sveikatos priežiūros ịstaigų autonomijos didinimą; valdymą, pagrịstą vertybių sistema; investicijas ị visuomenès sveikatą (poveikis elgsenos ir gyvensenos veiksniams); racionalų išteklių, skirtų sveikatos priežiūrai, paskirstymą; nacionalinę sveikatos priežiūros paslaugų kokybės sistemą (Janušonis, 2011; Magnussen et al., 2009).

Vykdoma sveikatos priežiūra privalo turèti tiesiogines sąsajas su sveikatos priežiūros lygiateisiškumu, efektyvumu, kokybe ir finansavimu. Teikiant sveikatos priežiūros paslaugas, procesas ne mažiau svarbus (o kartais svarbesnis) nei turinys. Tinkama etinè elgsena visais vadybiniais lygiais yra svarbi, kad reformos vyktų sėkmingiau (Janušonis, 2011). 
Piliečiams, besikreipiantiems ị sveikatos priežiūros organizacijas, svarbu gauti kokybiškas ir laiku e. sveikatos paslaugas. IKT paremta administravimo sistema internetu, gali užtikrinti administruojamos paslaugos skaidrumą, atsižvelgiant ị besikreipiančiu asmenų poreikius.

Šis tyrimas atliktas siekiant igyvendinti vartotojų lūkesčius atitinkančias administravimo paslaugas sveikatos priežiūros sistemoje - numatyti priemones, kaip galima efektyviau igyvendinti ir pletoti e. sveikatos komunikaciją, paremtą IKT administravimo sistema, bei pateikti, e. sveikatos administravimo sistemos komunikacijos rodikliu vertinimą, kurie užtikrintų e. paslaugų teikimo internetu kokybę ir tenkintų piliečiu lūkesčius.

Tyrimui atlikti buvo pasirinktas kokybinis tyrimo metodas. Tyrimo metu buvo apklausta 10 ekspertų sveikatos administravimo sistemos vadybininkų, dirbančių ịvairiose sveikatos priežiūros organizacijose. Buvo siekiama išsiaiškinti vadybos specialistų nuomonę, kokie svarbiausi ir dažniausiai vartotojų pageidaujami rodikliai e. sveikatos administravimo srityje.

Tyrimo metu buvo išaiškinta, kokie sveikatos administravimo komunikacijos rodikliai piliečių pageidaujami ir įvertintas sveikatos administravimo komunikacijos rodiklių reikšmingumas.

1 lentele. Sveikatos administravimo sistemos komunikacijos rodiklių vertinimo rezultatai

\begin{tabular}{|c|c|c|c|c|c|c|c|c|c|c|c|c|c|c|c|}
\hline \multirow{2}{*}{ Ekspertai } & \multicolumn{15}{|c|}{ Sveikatos administravimo sistemos rodikliai ir jų reitingas } \\
\hline & $\mathbf{a}$ & b & c & d & e & f & g & $\mathbf{h}$ & i & $\mathbf{j}$ & $\mathbf{k}$ & 1 & $\mathbf{m}$ & n & $\mathbf{0}$ \\
\hline 1-as ekspertas & 1 & 8 & 2 & 3 & & 9 & 7 & & & & 6 & & 5 & 4 & 10 \\
\hline 2-as ekspertas & 2 & & 10 & 5 & & 7 & 1 & 8 & & & 3 & 9 & 4 & 6 & \\
\hline 3- as ekspertas & 1 & 2 & 8 & 10 & & & 3 & & & & & & 7 & 5 & 9 \\
\hline 4-as ekspertas & 2 & 10 & 9 & 1 & 4 & 3 & 6 & 5 & 7 & 8 & 4 & & 3 & & \\
\hline 5-as ekspertas & 1 & & 4 & 7 & 8 & 6 & 3 & & 2 & 5 & & & & 9 & 10 \\
\hline 6-as ekspertas & & 7 & 4 & 9 & & & 5 & 8 & 3 & 1 & & 2 & & 10 & 6 \\
\hline 7-as ekspertas & 1 & 2 & & & 10 & & 3 & 8 & & & 4 & 7 & 9 & 5 & 6 \\
\hline 8-as ekspertas & 1 & 2 & 4 & 3 & & 5 & & 6 & 8 & & 7 & & 9 & & 10 \\
\hline 9-as ekspertas & 1 & 2 & 4 & & 3 & & & 5 & & 8 & 6 & 9 & 10 & & \\
\hline 10-as ekspertas & 1 & 4 & 8 & 3 & 9 & 6 & & 7 & 5 & & & 10 & & 2 & \\
\hline
\end{tabular}

Norint užtikrinti sèkmingą sveikatos paslaugų internetu administravimą ekspertai išrinko ir pasiūlè dažniausiai gyventojų pageidaujamų 15 rodiklių sąrašą:

a) laiku suteiktos gydytojo paslaugos užtikrinimas;

b) registracija pas sveikatos priežiūros specialistą IKT priemonėmis portale;

c) registravimo informacijos patikimumas;

d) informacijos saugumas;

e) registracijos grịžtamasis ryšys per mobiliąsias ir kompiuterines technologijas;

f) patogi darbui aplinka portale; 
g) pacientui prieinamos informacijos turinio aiškumas;

h) efektyvus, skaidrus ir laiku paslaugų administravimas;

i) kokybiškas pacientų ir administruojančių specialistų bendradarbiavimo valdymas;

j) administravimo paslaugų kokybès, orientuotos ị pacientą, gerinimas taikant naujas technologijas;

k) privatumo teisè / asmens informacijos apsauga;

1) palanki pacientui aplinka teikiant IKT konsultacijas tiesiogiai;

m) teisès aktų taikymas laiku;

n) administravimo veiklos konsultacija telefonu;

o) vieno langelio principo taikymas.

Ekspertu sveikatos administravimo komunikacijos rodiklių vertinimas pateiktas 1-oje lentelèje. Rodikliai buvo reitinguojami dešimties balų skalejje - nuo 1 iki 10. Penkiolikos rodiklių sąraše ekspertai galëjo reitinguoti 10 rodiklių.

Rodiklių svorio $k$ reikšmès išreikštos santykiu, parodančiu, kiek kartų atskiras rodiklis buvo paminètas (keliama kvadratu) iš balų sumos, kokị jis surinko (Augustinaitis et al., 2009). Kuo rodiklio balas yra mažesnis, tuo aukštesnè jo vieta reitingų eilèje (žr. 4 formulę).

čia:

$$
k=\frac{m^{2}}{\sum_{i=1}^{m} x_{i}}
$$

$m$ - suminis skaičius, parodantis, kiek kartų visi ekspertai paminèjo rodiklį,

$x_{i}$ - rodikliui suteiktas rangas, $\mathrm{i}=1,2, \ldots, m$.

Apskaičiuotos sveikatos administravimo sistemos komunikacijos rodiklių svorio $k$ reikšmès pateiktos 4 paveiksle.

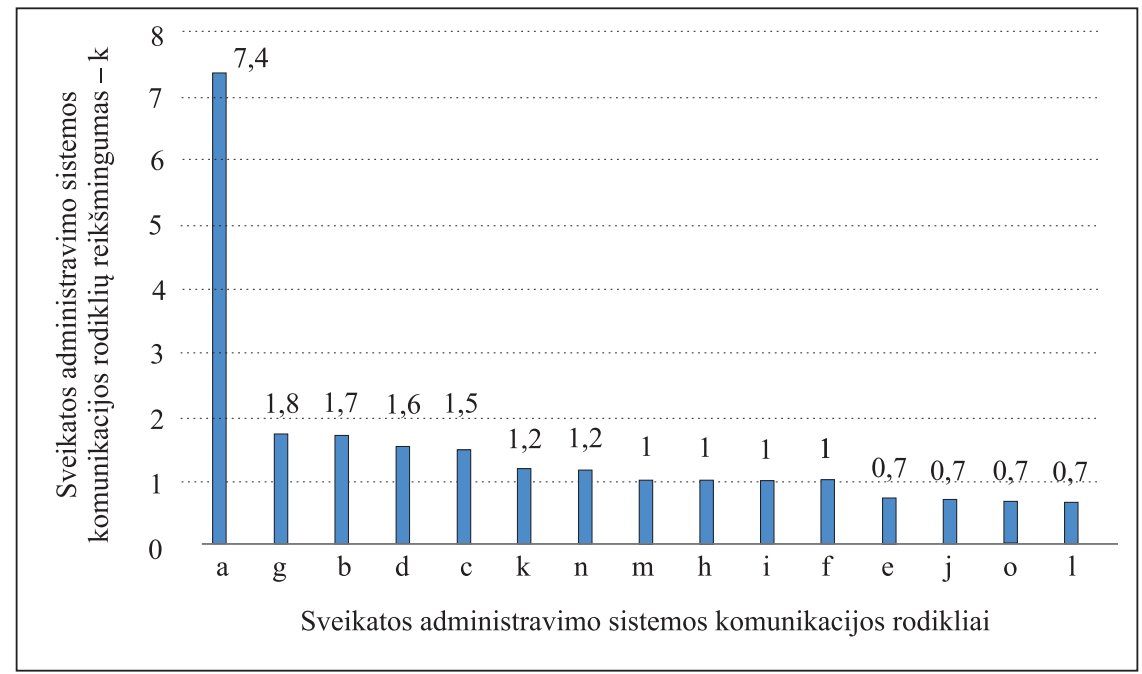

4 pav. Sveikatos administravimo sistemos komunikacijos rodiklių reikšmingumas 
Apskaičiuotos sveikatos komunikacijos rodiklių svorio $k$ reikšmės kinta nuo 7,4 iki 0,7. Sveikatos administravimo sistemos komunikacijos rodiklių reikšmingumą ekspertai ịvertino sudarydami šią eilès tvarką (žr. 4 pav.):

a) gydytojo paslaugos užtikrinimas laiku;

g) pacientui prieinamos informacijos turinio aiškumas;

b) registracija pas sveikatos priežiūros specialistą IKT priemonèmis portale;

d) informacijos saugumas;

c) registravimo informacijos patikimumas;

k) privatumo teisè / asmens informacijos apsauga;

n) administravimo veiklos konsultacija telefonu;

m) teisès aktų taikymas laiku;

h) efektyvus, skaidrus ir laiku paslaugų administravimas;

i) kokybiškas pacientų ir administruojančių specialistų bendradarbiavimo valdymas;

f) patogi darbui aplinka portale;

e) registracijos grịžtamasis ryšys per mobiliąsias ir kompiuterines technologijas;

j) administravimo paslaugų kokybès, orientuotos ị pacientą, gerinimas taikant naujas technologijas;

o) vieno langelio principo taikymas;

1) patogi pacientui aplinka teikiant IKT konsultacijas tiesiogiai.

Apskaičiuotos sveikatos komunikacijos rodiklių svorio $k$ reikšmès parodo, kad piliečiams yra ypatingai svarbu laiku gauti sveikatos administravimo sistemos paslaugas, kurių turinys lengvai suprantamas - paprasta ir aiški navigacija užsakant paslaugą internetu.

\section{Išvados}

Igyvendinant e. sveikatos administravimo komunikacijos paslaugas svarbu teikti piliečių lūkesčius tenkinančias paslaugas. Daugelyje dalykinių e. sveikatos sričių didèja veiklos procesų įvairovè. Tobulejjančios IKT leidžia supaprastinti šių procesų valdymą ir informacijos pateikimo būdus.

Sukurta sąveiki e. paslaugų platforma - e. paslaugų portalas turètų organizuoti saugų ir veiksmingą visų e. sveikatos sistemų darbą. E. sveikatos portalo moduliai turètų adaptuoti įvairaus pasirengimo gyventojus ir pacientus.

Sveikatos komunikacijos rodiklių svorio $k$ reikšmès parodo, kad piliečiams yra ypatingai svarbu gydytojo paslaugą gauti laiku, tai didžiausią reikšmę turintis rodiklis 7,4. Reikšmingų rodikliu pirmo penketo sąraše yra šie rodikliai: pacientui prieinamos informacijos turinio aiškumas, registracija pas sveikatos priežiūros specialistą IKT priemonèmis portale, informacijos saugumas, registravimo informacijos patikimumas, privatumo teisé ir asmens informacijos apsauga, administravimo veiklos konsultacijos telefonu. 
Sveikatos administravimo rodiklių svorio $k$ reikšmės parodo, kad patogių portalo sąsajų gyventojams įdiegimas neabejotinai darys įtaką administracinès naštos mažinimui ir e. sveikatos administravimo sistemos tobulinimui.

\section{Literatūra}

Augustinaitis, A. et al. 2009. Lietuvos e. valdžios gairès: ateities įžvalgu tyrimas. Vilnius: Mykolo Romerio universiteto Leidybos centras.

Dzemydienè, D. ir Naujikienè, R. 2011. Daugelio kriterijų grịžtamojo ryšio vertinimo modelis elektroninių viešųjų paslaugų igyvendinimo situacijos analizei. Informacijos mokslai, 56: 19-30.

Naujikienè, R. 2011. Indicators Influencingthe Usability of Public E-services. Social technologies'11. ICT forsocialtransformations: Conference Proceedings.Vilnius: Mykolo Romerio universitetas, p.106-107.

Dzemydiené, D. et al. 2010. Evaluationof Security Disturbance Risksin Electronic Financial Payment Systems. Intellectual Economics. 2010, 2 (8): 21-29.

Dzemydienè, D.; Naujikienè, R. 2007. Elektroninių viešujų paslaugų teikimo pavyzdžių analizè. Informacijos mokslai, 42-43: 226232.

EK komunikatas. 2004. E-Health-Making Healthcare Betterfor European Citizens: An Action Planfor a European e-Health Area, Nr. COM/2004/356 [interaktyvus]. [žiūrèta 2013-04-18]. <http://eur-lex.europa.eu>.

EK komunikatas. 2010. 2011-2015 m. Europos e. valdžios veiksmų planas IRT naudojimas siekiant pažangios, darnios ir novatoriškos valdžios. Briuselis, Nr. COM/2010/743.

Gascó, M. 2010. Approaching E-Government Interoperability. Social Science Computer Review [interaktyvus]. [žiūrèta 2013-02-10]. $<$ http://ssc.sagepub.com/>.

Goldkuhl, G. and Röstlinger, A. 2010. Development of public e-services - a method outline. Paper accepted to the 7th Scandinavian Workshop on E-Government (SWEG-2010) [interaktyvus]. January 27282010 [žiūrèta 2013-04-18]. <http://www. vits.org/publikationer/dokument/722.pdf>.

Janušonis, V. 2011. Sveikatos priežiūros reformos: teoriniai požiūriai ir praktiniai aspektai. Sveikatos mokslai, 21(4): 5-11.

Janušonis, V. 2011. Irodymais pagrịstas sveikatos priežiūros organizacijų valdymas. Tiltai [interaktyvus]. 4(57): 1-10 [žiūrèta 2013-04-20]. <http://www.ku.lt/leidykla/files/2012/09/tiltai_2011_457.pdf>.

Magnussen, J.; Vrangbaek, K.; Saltman, R. B. 2009. Nordic health care systems: recent reforms and current policy challenges. Berkshire: Open University Pres.

Lietuvos Respublikos Vyriausybès $2011 \mathrm{~m}$. vasario 23 d. nutarimas Nr. 213 „Dèl administracinès naštospiliečiams ir kitiems asmenims nustatymo ir iqvertinimo metodikos patvirtinimo“.

Lietuvos Respublikos sveikatos apsaugos ministro $2007 \mathrm{~m}$. spalio 9 d. isakymas Nr. V-811 „Dèl Lietuvos e. sveikatos 20072015 metų plètros strategijos patvirtinimo“.

Lietuvos e. sveikatos strategija: kontekstas argumentacija ir igyvendinimo rekomendacijos. Lietuvos Respublikos sveikatos apsaugos ministerija, 2007.

Pardo, T., A.; Nam, T; Burke, G., B. E-Government Interoperability: Inter action of Policy, Management, and Technology Dimensions. Social Science Computer Review [interaktyvus]. 2011 [žiūrèta 201303-20]. <http://ssc.sagepub.com/>. 
Verdegem, P.and Hauttekeete, L. User Centered e-Government: Measuring user Satisfaction of online Public Servines. IADIS International Journalon WWW/Internet [interaktyvus]. 2007, 5(2): 165-180 [žiūrèta 2013-04-09]. <http://www.iadis.net/dl/final uploads/2007520112.pdf>.

\section{E-HEALTH ADMINISTRATION SYSTEM COMMUNICATION INDICATORS AND THEIR SIGNIFICANCE ASSESSMENT}

\section{Ramute Naujikienè}

Mykolas Romeris University, Lithuania, riman@mruni.eu

Summary. It is important to provide services meeting the needs of citizens while implementing e-health administration in e-space. The development of ICT allows the simplification of administrative processes. ICT affects the variety of methods of information collection, dissemination and management. While providing e services, it is important to create an interoperable e services platform that enables the organization of distributed IS and DB interactions. It is particularly important to use ICT-based solution, and understand user communication patterns. To promote the active participation of citizens-citizens should participate in the improvement of communication processes shaping the diversity of opinion and offering alternative solutions. The paper presents the health administration field communication indicators and their significance assessment which makes health communication processes more efficient.

Keywords: e-services, e-health, communication, administrative burden, interoperability, information and communication technology. 